\title{
ОСОБЕННОСТИ ГОСУДАРСТВЕННОЙ РЕГИСТРАЦИИ ПРАВ НА НЕДВИЖИМОЕ ИМУЩЕСТВО И СДЕЛОК С НИМ В КРЫМСКОМ ФЕДЕРАЛЬНОМ ОКРУГЕ
}

Аннотация: Предметом исследования являются отличительные особенности государственной регистрации прав на недвижимое имущество и сделок с ним на территории Крымского федерального округа. В статье рассматривается действующее законодательство республики Крым в области государственной регистрации недвижимого имущества и сделок с ним. Сравниваются положения закона «Об особенностях регулирования имущественных и земельных отношений на территории Республики Крым» с нормами Федерального закона «О государственной регистрации прав на недвижимое имущество и сделок с ним»и Гражданского кодекса РФ. Методологическую основу исследования составляют общие и частно - научные методы познания. Автор использует метод анализа, статистический, сравнительно - правовой метод. Автор указывает на отдельные особенности законодательства республики Крым, в сфере государственной регистрации прав на недвижимое имущества и сделок с ним. Выявленные особенности имеют своей ичелью организацию оборота недвижсмого имущества с учетом особенностей, сформировавшихся на территории республики в период ее нахождения под юрисдикцией Украины и исключить злоупотребления в переходный период. По мнению автора, опыт делегирования полномочий специально созданным органам исполнительной власти субъекта РФ может быть использован в иных регионах России.

Ключевые слова: Крымский федедеральный округ, регистрация прав, сделки с недвижимостью, Госкомрегистр, оборот земель, ограничения, особенности законодательства, переходньй период, Росреестр, аренда.

Abstract: The subject of this research is the distinct specificity of the state registration of rights to real estate and real estate transactions within the Crimean Federal Okrug. The article examines the current legislation in the Republic of Crimea in the area of real estate. A comparison is conducted on the law "On Peculiarities of Regulation of Property and Land Relations in the Republic of Crimea" with the norms of the Federal Law "On State Registration of Real Rights on Real Estate Property" of the Civil Code of the Russian Federation. The author points out specific aspects within the Crimean legislation with regards to state registration of real rights and real estate. The discovered peculiarities are intended to organize turnover of real estate with consideration of the peculiarities that has formed within the territory of the Republic during its time under Ukrainian jurisdiction, and eliminate abuse during the transitional period. In author's opinion, the experience of delegation of authority to the specially created executive branches of the constituent of the Russian Federation can be implemented in other regions of Russia. Keywords: Crimean Federal Okrug, Registration of rights, Real estate transactions, Cadastre, Land sale, Limitations, Specificity of legislation, Transitional period, Rosreestr, Rent.

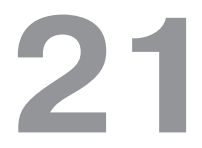

марта 2014 года Президентом России был подписан Федеральный конституционный закон № 6-ФКЗ «О принятии в Российскую Федерацию Республики Крым и образовании в составе Российской Федерации новых субъектов Республики Крым и города федерального значения Севастополя». Таким образом, республика Крым и г. Севастополь стали новыми полноправными субъектами России. Появление новых субъектов Российской Федерации потребовало включения в экономический оборот объектов недвижимого имущества, расположенных на новых территориях с одновременным подтверждением их правового статуса со стороны Российской Федерации. Россия и республика Крым более 20 лет жили в разных правовых системах. В этой связи возникла необходимость приведения законов, действующих на территории Крыма в соответствие с российским законодательством, чтобы новый субъект мог полноценно развиваться в составе федерации. Изложенные обстоятельства делают тему настоящего исследования особо актуальной. 
До 1 января 2017 г. на территориях Республики Крым и г. Севастополя особенности регулирования земельных, имущественных, градостроительных и лесных отношений, а также отношений в сфере государственной регистрации прав на недвижимое имущество и сделок с ним, а так же кадастрового учета объектов недвижимости могут быть установлены нормативными правовыми актами Республики Крым и города федерального значения Севастополя по согласованию с федеральными органами исполнительной власти, уполномоченными на осуществление нормативно-правового регулирования в соответствующих сферах [1]. Сегодня такими полномочиями наделен Государственный комитет по государственной регистрации и кадастру Республики Крым на основании соглашения между Федеральной службой государственной регистрации, кадастра и картографии (Росреестр) и Советом министров Республики Крым «О передаче осуществления части полномочий в сфере государственной регистрации прав на недвижимое имущество и сделок с ним и государственного кадастрового учета на территории Крымского федерального округа» [2]. Государственный комитет является исполнительным органом государственной власти Республики Крым, осуществляющий функции по государственной регистрации прав на недвижимое имущество и сделок с ним, осуществлению государственного кадастрового учета, предоставлению государственных услуг по регистрации прав на недвижимое имущество и сделок с ним, государственному кадастровому учету недвижимого имущества, кадастровой оценке объектов недвижимости, землеустройству, государственному мониторингу земель на территории Республики Крым. Комитет осуществляет свои функции, основываясь на нормах Федерального закона №122-ФЗ от 21.07.1997 «О государственной регистрации прав на недвижимое имущество и сделок с ним», с учетом положений Закона Республики Крым «Об особенностях регулирования имущественных и земельных отношений на территории Республики Крым» №38-ЗРК от 30.07.2014 [3, с.1]. Таким образом, в Крымском федеральном округе полномочия в сфере государственной регистрации прав на недвижимое имущество и сделок с ним, а так же кадастрового учета возложены не на территориальные подразделения «Росреестра», а на специально созданный исполнительный орган государственной власти субъекта федерации. При этом, на территории республики сформированы и действуют территориальные отделы Росреестра, на которые возложены задачи по участию в осуществлении методической помощи, ко- ординации и контроля деятельности уполномоченных органов исполнительной власти субъектов Российской Федерации в составе Крымского федерального округа по осуществлению полномочий территориальных органов Росреестра [4, с.1].

Закон Республики Крым №38-ЗРК от 30.07.2014. устанавливает особенности регулирования земельных и имущественных отношений и государственной регистрации прав на недвижимое имущество и сделок с ним на территории Республики Крым. Его существенной особенностью является факт признания юридически действительными прав, ограничений, обременений зарегистрированных на территории республики Крым физическими и юридическими лицами в соответствии с украинским законодательством до принятия новых субъектов в Российскую Федерацию. Перечень подтверждающих наличие ранее возникших прав на объекты недвижимого имущества утвержден Постановлением Совета министров Республики Крым № 264 от 11.08.2014 [5]. Основаниями для государственной регистрации наличия, возникновения, прекращения, перехода, ограничения (обременения) прав на недвижимое имущество и сделок с ним являются акты, изданные органами государственной власти или органами местного самоуправления, договоры и сделки совершенные в соответствии с законодательством, действовавшим на момент совершения сделки, свидетельства о приватизации жилых помещений, свидетельства о праве на наследство, вступившие в законную силу судебные акты, а так же иные акты передачи прав на недвижимое имущество. Документами, подтверждающими наличие ранее возникших прав на объекты недвижимого имущества, являются дубликаты документов, выданные нотариусами, органами государственной власти, органами местного самоуправления, органами приватизации, копии архивных правоустанавливающих документов, выданные государственным архивом.

Законодательством Украины в целях государственной регистрации применялись такие основания возникновения прав, как эмфитевзис и суперфиций, отсутствующие в российском гражданском праве, но имеющие в нем соответствующие аналоги. В этой связи законом №38-ЗРК от 30.07.2014 дается толкование юридических понятий, используемые в области имущественных отношений на территории республики в соответствии с действующим Российским законодательством. Например, право пользования чужим земельным участком для сельскохозяйственных нужд (эмфитевзис), пользования чужим земельным участком для строительства (суперфиций) и право на временное 
DOI: $10.7256 / 1811-9018.2015 .9 .16210$

При цитировании этой статьи сноска на доі обязательна

\section{Право и политика 9 (189) $\bullet 2015$}

пользование земельного участка соответствуют аренде земельных участков, право коммунальной собственности территориальных громад признается собственностью соответствующих муниципальных образований.

Законодательство Республики Крым уделяет особое внимание вопросам оборота земель на территории республики. Если права на объекты недвижимости признаются действительными без их государственной регистрации в соответствии с федеральным законом о регистрации № 122-Ф3 от 21.07.1997, то в отношении зарегистрированных в соответствии с украинским законодательством ограничений (обременений) земельных участков, ст.3 закона № 38-ЗРК от 31.07.2014 обязывает физические и юридические лица в срок до 01.01.2017 заключить договоры аренды и оформить права на земельные участки в соответствии с Гражданским и Земельным кодексами России. После истечения указанной даты все ограничения (обременения) прав, не предусмотренные законодательством Российской Федерации, прекращаются и исключаются из Единого реестра прав на недвижимое имущество и сделок с ним без подачи заявления заинтересованных лиц. Анализ положений закона № 38-3РК от 31.07.2014 показывает, что иностранные лица приобретают земельные участки с ограничениями, установленными законодательством РФ. Единственное ограничение в отношении иностранных лиц установлено п. 3 ст. 15 Земельного кодекса РФ. В соответствии с ней: «иностранные граждане, лица без гражданства и иностранные юридические лица не могут обладать на праве собственности земельными участками, находящимися на приграничных территориях, перечень которых устанавливается Президентом Российской Федерации в соответствии с федеральным законодательством о Государственной границе Российской Федерации, и на иных установленных особо территориях Российской Федерации в соответствии с федеральными законами» [6, с.422]. Сейчас в отношении Республики Крым сведения об установлении приграничных территорий отсутствуют [7]. Вместе с тем, согласно ч.2 ст. 2 закона № 38-3РК от 31.07.2014, право собственности на земельные участки и иные объекты недвижимого имущества, возникшее до вступления в силу Федерального конституционного закона от 21 марта 2014 года № 6-ФК3, на территории Республики Крым у физических и юридических лиц, включая иностранных граждан, лиц без гражданства и иностранных юридических лиц, сохраняется. При этом иностранные граждане и иностранные юридические лица не вправе отчуждать каким-либо образом земельные участки иному иностранному гражданину, лицу без гражданства, юридическому лицу, доля в уставном (складочном) капитале которого принадлежит иностранным лицам, или иностранному юридическому лицу, а также вносить в уставный (складочный) капитал или в паевой фонд иностранного юридического лица, если перечисленные лица в соответствии с законодательством Российской Федерации не вправе приобретать в собственность указанные земельные участки. Статьей 12 указанного закона установлено так же общее ограничение на приобретение земель сельскохозяйственного назначения до принятия органами государственной власти республики правил землепользования и застройки. До 1 января 2016 года запрещается совершения сделок по отчуждению паев и земельных участков, предназначенных для ведения товарного сельскохозяйственного производства.

В настоящее время на территории Крымского федерального округа весьма остро стоит вопрос о гарантировании «юридической чистоты» сделок-отсутствия арестов и запретов в отношении недвижимого имущества, которые были зарегистрированы на Украине до вхождения республики в состав России. В соответствии со ст. 28 Ф3 от 21.07. 1997 г. № 122 -Ф3 «О государственной регистрации прав на недвижимое имущество и сделок с ним» все ограничения (обременения), в т.ч. аресты, ипотека должны быть зарегистрированы в ЕГРП и считаются возникшими с момента такой государственной регистрации. Органы, наложившие арест (запрещения), ограничения прав обязаны направлять постановления о наложении таких запретов, ограничении в орган, осуществляющий государственную регистрацию. Таким образом, арест, запрет, иное ограничение, наложенное после 07.03.2014, считается возникшим только после их государственной регистрации в ЕГРП в соответствии с российским законодательством. Очевидно, что в связи с этим в Крымском федеральном округе наблюдается аномальное количество заявлений на государственную регистрацию прав, подаваемых нотариусами. Согласно статистике «Росреестра», только в 1 квартале текущего года нотариусами на территории республики было подано 1683 заявлений о государственной регистрации прав - 3,34 \% от общего количества заявлений [8]. При этом средний показатель по России за аналогичный период составляет 0,17 \%, т.е. меньше почти в 20 раз. Всего в 1 квартале 2015 года на территории Крымского федерального округа согласно сведениям «Росреестра», в органы, осуществляющие функции государственной регистрации поступило 50368 заявлений от физических и юридических лиц на регистрацию прав. На осно- 
вании поданных заявлений было зарегистрировано 27038 прав, ограничений (обременений) и сделок с недвижимым имуществом. Приведенные показатели существенно ниже такого региона как Иркутская область, имеющего сходную численность населения. За аналогичный период на территории этого субъекта было подано 127727 заявлений и совершено 100125 регистрационных действий [9]. Статистические данные позволяют предположить, что по окончании периода, регулируемого нормативными актами республики Крым, появится необходимость продления переходного на некоторый срок с целью обеспечения возможности регистрации прав на имущество, возникших до 21.03.2014 и окончательной адаптации новых субъектов в Российское правовое поле.

Таким образом, в настоящее время на территории Крымского федерального округа функции «Росреестра» возложены на специально созданный орган исполнительной власти субъекта Российской Федерации - Государственный комитет по государственной регистрации и кадастру Республики Крым. Ему впервые в новейшей истории России делегированы полномочия в сфере государственной регистрации прав на недвижимое имущество и сде- лок с ним. В своей деятельности Государственный комитет руководствуется нормами гражданского законодательства России и законом о регистрации № Ф3-122 от 21.07.1997 с учетом особенностей, установленных законом Республики Крым № 38ЗРК от 31.07.2014. Особенности носят временный характер и касаются, прежде всего, ограничений на приобретение земельных участков иностранными гражданами, приобретении прав и осуществления сделок с землями сельскохозяйственного назначения. Регулирование земельных отношений на территории республики можно считать компромиссным вариантом на время переходного периода до 01.01.2017 г., который необходим для упорядочения государственного кадастрового учета земель сельскохозяйственного назначения, снижение риска совершения мошеннических действий с земельными участками и объектами недвижимого имущества приведения сложившейся системы государственной регистрации в соответствие с Российским законодательством в сжатые сроки. По нашему мнению, опыт по делегированию полномочий специально созданным органам исполнительной власти субъекта РФ может быть использован в иных регионах России.

\section{Библиография:}

1. Федеральный конституционный закон № 12-ФКЗ «О внесении изменений в Федеральный конституционный закон «О принятии в Российскую Федерацию Республики Крым и образовании в составе Российской Федерации новых субъектовРеспублики Крым и города федерального значения Севастополя». // Рос. газ. - 2015. - 23 июля

2. Распоряжение Правительства Российской Федерации от 17.07.2014г. №1335-р. // Собрание законодательства РФ. 28.07.2014г. - №30. - Ст. 4364.

3. Положение о Государственном комитете по государственной регистрации и кадастру Республики Крым: приложение к постановлению Совета министров Республики Крым от 27 июня 2014г. №164 (в редакции постановления Совета министров Республики Крым от 11 августа 2014г. № 265). [Электронный ресурс]. Правительство Республики Крым [Сайт]. Режим доступа: http://rk.gov.ru/rus/docs/post/post1.htm?page=60. (дата обращения: 03.08.2015г.).

4. Положение об Управлении Федеральной службы государственной регистрации, кадастра и картографии по Крымскому федеральному округу: приложение к Приказу Росреестра от 05.09.2014г., № П/417 «Об утверждении Положения об Управлении Федеральной службы государственной регистрации, кадастра и картографии по Крымскому федеральному округу».[Электронный ресурс]. Федеральная служба государственной регистрации, кадастра и картографии [Сайт]. Режим доступа: https://rosreestr.ru/site/about/struct/territorialnye-organy/upravlenie-rosreestra-po-krymskomu-federalnomuokrugu/\#1 (дата обращения: 04.08.2015г.).

5. Об утверждении перечня документов, подтверждающих наличие ранее возникших прав на объекты недвижимого имущества и необходимых для государственной регистрации: Постановление Совета министров Республики Крым от 11.08.2014г., № 264. [Электронный ресурс]. Правительство Республики Крым [Сайт]. Режим доступа: http://rk.gov.ru/rus/ docs/post/post1.htm?page=60. (дата обращения: 31.07.2015г.).

6. Земельный кодекс РФ с комментариями к последним изменениям. М.: Эксмо, 2015. 656 с.

7. Об утверждении перечня приграничных территорий, на которых иностранные граждане, лица без гражданства и иностранные юридические лица не могут обладать на праве собственности земельными участками: указ Президента РФ от 9 января 2011г., № 26 //Собрание законодательства РФ, 10.01.2011. - № 2. - Ст. 268.

8. Сведения о деятельности Росреестра по государственной регистрации прав на недвижимое имущество и сделок с ним (в разрезе центрального аппарата и территориальных органов) - январь-март 2015г. [Электронный ресурс]. Федеральная служба государственной регистрации, кадастра и картографии [Сайт]. Режим доступа: https://rosreestr.ru/site/open-service/ statistika-i-analitika/statisticheskaya-otchetnost/?clear_cache=Y. (Дата обращения: 04.08.2015 г.) 
DOI: $10.7256 / 1811-9018.2015 .9 .16210$

При цитировании этой статьи сноска на доі обязательна

\section{Право и политика $9(189) \cdot 2015$}

9. Сведения о деятельности Росреестра по государственной регистрации прав на недвижимое имущество и сделок с ним (в разрезе центрального аппарата и территориальных органов) - январь-март 2015г. [Электронный ресурс]

10. Бодянская Е.А. Проблемы правового регулирования и правоприменения использования земель в интересах обороны и безопасности // Национальная безопасность / nota bene. - 2014. - 6. - C. 932 - 939. DOI: 10.7256/2073-8560.2014.6.13565.

\section{References (transliterated):}

1. Bodyanskaya E.A. Problemy pravovogo regulirovaniya i pravoprimeneniya ispol'zovaniya zemel' v interesakh oborony i bezopasnosti // Natsional'naya bezopasnost' / nota bene. - 2014. - 6. - C. 932 - 939. DOI: 10.7256/2073-8560.2014.6.13565. 